\title{
WAYS OF FORMATION OF PROFESSIONAL COMPETENCE OF FUTURE MOTOR TRANSPORT SPECIALISTS
}

\author{
Artem Dundiuk ${ }^{1}$ \\ ${ }^{I}$ Teacher of Special Disciplines Rivne Motor Transport Vocational College of the National University of \\ Water Management and Nature Management, Rivne, Ukraine, e-mail: artdy@ukr.net, ORCID ID: \\ http://orcid.org/0000-0003-4600-0164
}

\begin{abstract}
The article considers the question of ways to improve the quality of training of future technicians-technologists of motor transport in colleges. Considerable attention is paid to the periods of such training: introductory, preparatory, mastering the profession, improving the basics of professional skills and specialization of future professionals. Labor practice is defined as a way to improve the quality of professional training. In the process of labor practice, students acquire professional skills and abilities: the use of rolling stock and its profitability; development of technological instructions; to carry out work to ensure labor protection; execution of drawings of assembly units and details; use of professionally profiled knowledge; practical skills of accidentfree driving and maintenance of the vehicle; formation of personal qualities of a professional; analysis of own professional activity. Another way of training is to participate in research work. Research work of students within the curriculum is mandatory and includes: writing scientific papers on a specific topic and professionally-oriented, special disciplines, specialization courses and electives; performance of laboratory, practical, seminar and independent tasks; control works containing elements of problem search; performing atypical research tasks. The following methods were used to study the conditions for the formation of professional competence of technicianstechnologists: theoretical - synthesis, analysis, generalization; empirical - observations, interviews, questionnaires, testing, interviews, surveys. Research work of students in extracurricular time involves: participation in the work of subject research groups; problem groups, sections, laboratories; participation in state budget or self-supporting scientific works. One of the basic links of formation of the expert is his participation in scientific conferences.
\end{abstract}

Keywords: future technicians-technologists, college, training of motor transport specialists, industrial practice, research work.

JEL Classification: I24, I29

Formulas: 0; fig.: 0; tabl.: 0; bibl.: 13

Introduction. Improving the quality of professional education is an urgent problem for the whole world community and for Ukraine. Solving this problem is associated with rethinking the purpose and results of education, optimizing the methods and technologies of the educational process, modernizing the content of education. Training of qualified personnel that meet modern requirements in the labor market has been identified as one of the priority areas of state policy for the development of education. The country needs competitive specialists, capable of creativity, professional development, with such qualities as initiativity, sociability, tolerance, efficiency, adaptability, professional mobility.

To achieve this, it is necessary to create conditions for personal development, creative self-realization of every citizen of Ukraine, education of a generation of people capable of working and learning throughout life, to preserve and increase the values of national culture and civil society. The introduction of a competency-based approach in higher education institutions allows us to fulfill the task.

Literature Review. The attention of many scientists is focused on the problem of formation of professional competence of future specialists in the process of 
studying in a higher educational institution. The transition of the world community to the information society, where the priority is not just the accumulation of future specialists knowledge, subject skills and abilities, but the formation of learning skills, mastery of information retrieval skills, the ability to self-study throughout life determines the interest of scientists in professional competence [6]. The problem of competence is thoroughly studied in the works of S.Goncharenko, O. Dakhin, B. Elkonin, A. Markov and others. Psychological problems of formation of professional skills and qualities are considered by I. Bekh, G. Ball, V. Semichenko.

Issues of professional training on the basis of the competence approach are studied in the works of V. Anishchenko, N. Bibik, M. Vasylieva, N. Dementieva, A.Mykhailychenko, O. Ovcharuk and others. The definition of key competencies is given in the works of I. Zymna, G. Selevka, P. Tretyakov, T. Shamov and others.

The issue of forming the professional competence of future road transport specialists is extremely important, because the modern labor market needs qualified competitive specialists who are able to perceive and use in practice new scientific ideas, technical tools and methods of modern production. All this requires a higher education institution to train a competitive young specialist.

Aims. The purpose of the article is an attempt to substantiate the ways of formation of professional competence of the future specialist of motor transport, to define the components that determine the professional growth of the future technician-technologist.

Methods. The following methods were used to study the conditions for the formation of professional competence of technicians-technologists: theoretical synthesis, analysis, generalization; empirical - observations, interviews, questionnaires, testing, interviews, surveys.

Results. The initial stage of professionalization (choice of field of activity, search for a place in the professional community, social adaptation and selfrealization) is interpreted by scientists as a key point that determines the entire course of further human life. An important component of this stage is the period of study at the university, where the future specialist receives the necessary knowledge and skills, meets with senior colleagues, and clarifies his initial idea of the activities to which he decided to devote himself when entering the educational establishment [8].

Students are a special social category, a community, which is organizationally united by the institute of higher education. Students are defined as a group, the purpose of which is to learn an organized program of socio-professional qualities; prepare for important social functions: professional, cultural, socio-political, family and more. The main areas of students' life are professional training, personal growth and self-affirmation, development of intellectual potential, spiritual enrichment, moral, aesthetic, physical self-improvement. A student of a higher educational institution is a young person, characterized by a professional orientation, and prepares for a highly qualified performance as a specialist in a certain professional field [9].

Studying at a university is a new social environment for a young person, which forms the social maturity in terms of acquiring new special knowledge, skills and 
abilities. The future specialist prepares for professional activity in the process of learning, through creative cognitive activity.

Professional training in higher education establishment for the future specialist begins during the formation of professional knowledge, skills and abilities and mastering the methods of professional and creative activity. The real activity of the student includes theoretical knowledge. During their studies at the university, students study the theoretical components (cycle of humanities, general economics, natural sciences). System integrated sciences is a general prerequisite for mastering the methods of solving production problems. Conceptual form of arming with knowledge should become a way to achieve a practical professional goal. An important element of the theoretical component are professionally oriented disciplines that promote students' mastery of theoretical knowledge about the nature and functions of professional culture. Professional culture is based on moral and ethical beliefs, innovative nature of thinking and a systematic approach to the analysis of complex production situations.

A specialist with higher education must acquire not only knowledge, skills and abilities, but also independently develop the means to achieve professional goals. For this purpose the mechanisms must be formed to plan their activities, program their actions, evaluate results and correct them. One of the priorities of the educational process is to teach students independent cognitive and exploratory activities. Under the independent cognitive activity of students we understand a set of efforts that enrich intellectual sensitivity and promote in-depth independent search of knowledge that enriches professional life experience, skills and abilities and provide further professional self-improvement of the future specialist under the guidance of the teacher [1].

Independent study of scientific, educational, artistic or popular science literature is the main method of self-improvement. An important condition for the effectiveness of students' self-education is the possession of rational methods of independent work. Independent work of students contributes to the formation of initiative, discipline, accuracy, sense of responsibility, which are necessary for the future specialists' educational and professional activities. The desire of the future specialist to improve their achievements, to ensure the compliance of the internal development of the individual to the requirements of society determine the needs and motives that play an important role in achieving the goals of self-education. To resolve this internal contradiction of the individual there is a desire for self-education, which contributes to the continuous professional self-improvement of students in order to improve their skills. I. Rodygina believes that the obligatory and indispensable condition for success in activity, regardless of the general and mental potential of a person, is positive motivation, deep and active interest, the desire to achieve the goal of this activity [10]. Motivated learning is an important condition for self-education of future specialists in motor transport, because the set of needs and motives, along with the purposefulness of the future specialist, determine the meaning of his educational and cognitive activities. The activity of the individual depends on the formation and realization of the need for self-education, motives and goals of self-education, and 
their development is associated with the development of competence as an integrative property of man.

Fundamental theoretical training not only arms the future specialist of motor transport (technician-technologist) with the knowledge necessary for the full performance of his professional functions, but also prepares him to work in a rich information environment, for continuous training, self-improvement, professional development and professional development. Professional development that occurs in the process of theoretical training also provides the development of professional selfawareness, ability to reflect and introspect.

During the training period, in addition to the actual acquisition of knowledge, the professional activity of the future motor transport specialist (techniciantechnologist) begins.

Labor practice is important in the formation of professional competence. Labor practice is a component of the educational process. It is a necessary means of professional training of future technicians. Organized in unity with the educational and extracurricular activities of students, the practice forms the social activity of future professionals, develops students' interest in studying the cycle of mathematical, natural, humanities, general economics, vocational disciplines, logical abilities and skills of independent research.

Nowadays, much attention is paid to the problem of organizing the practical training of future professionals. Theoretical aspects of the organization of labor practice were developed by a number of researchers: M. Dyachenko, O. Bezpalko, I. Zvereva, N. Nychkalo. The organization of labor practice is an important scientific problem, as it aims to improve the process of professional training and promotes the connection of theory and practice [11].

In the process of labor practice, students independently process professional literature, systematically observe and analyze the production process, and study the experience of professionals. This period of the educational process should be considered as an opportunity to improve the skills of research work on the issues of professional and practical training, the practical orientation of professional disciplines.

During the introduction to the profession the characteristic of students are: mastering the forms, methods, tools, the latest technologies of the production process in enterprises of different types; formation of skills to apply theoretical knowledge in practice, awareness of the professional significance of this knowledge; forming the need for continuous improvement of professional knowledge, and professional skills; development of creative initiative, realization of personal creative potential; development of research skills in a specific professional activity.

In the process of professional and practical training, you can select certain periods, each of which is characterized by specific ways of its implementation:

- introductory - acquaintance of students with the content of their future profession, the traditions of the educational institution, the conditions of study, the rules and procedure, etc. If possible, students are introduced to the company, where they can work after graduation; 
- preparatory - its main purpose is the preliminary mastering by students of the basics of the profession - labor techniques, operations, which consist of a holistic labor process, characteristic of the content of the profession (specialty) being studied. In the process of this period, students develop primary skills - a kind of foundation for the subsequent formation of the foundations of professional skills;

- mastering the profession - the main period of professional and practical training, during which the formation, development of professional skills of future professionals happens. The material content of professional and practical training in this period is the performance by students of characteristics of the mastered profession, educational and production work, functions, responsibilities, which are gradually becoming more complicated. At the same time, students must perform training and production work in compliance with the required rhythm and pace, quality and compliance with occupational safety requirements;

- improvement of the basics of professional skills and specialization of future professionals - the final period of professional and practical training, during which they perform training and production work that meets the content and level of complexity of the requirements defined by the educational and qualification characteristics of government standards. At the end of this period, students perform production work with productivity equal to the productivity of skilled workers and specialists of the appropriate level of qualification. This period includes the development of students' professional skills and abilities in the process of performing complex work of a complex nature both in the conditions of educational workshops and in the conditions of real production during the production and pre-graduation practice [13].

During the internship, students master a system of professional skills, namely: to organize the efficient use of rolling stock and its cost-effective operation; develop technological instructions and conduct production briefings; to organize work in accordance with the requirements of life safety and labor protection; perform drawings of assembly units and drawings of parts with the necessary calculations; to use professionally-profiled knowledge and practical skills for accident-free driving and maintenance of the vehicle; to carry out research work, to form personal qualities of the professional; analyze their own professional activities, as well as colleagues, students-interns.

Labor practice is an important component of professional training of future professionals and is aimed at consolidating and implementing acquired subject and professional knowledge, skills and abilities necessary for future professional activity, as well as a means of creative development and self-development, formation of professionally significant qualities and readiness of students to innovation.

During this period comes a comprehensive understanding and generalization of theoretical and practical information about the patterns of personality formation of the future specialist of road transport, substantiation of the nature of the phenomenon of personality formation as a systemic formation, identification of mechanisms of its formation. 
An important factor in improving the content and forms of training of specialists in higher education is research work. In the university research work of students is carried out in the following areas: 1) educational research, which is an integral part of the educational process, and is included in the calendar-thematic and educational programs as mandatory for all students; 2) research work carried out outside the educational process on a voluntary basis within the student scientific and creative society [5].

Research work of students within the curriculum is mandatory for every student and covers almost all forms of educational work:

- writing scientific abstracts on a specific topic in the process of studying the discipline of the socio-humanitarian cycle, fundamental and vocational, special disciplines, specialization courses and electives;

- performance of laboratory, practical, seminar and independent tasks, control works containing elements of problem search;

- performance of atypical tasks of research type during the period of labor practice and by orders;

- preparation and defense of term papers and dissertations related to scientific issues of the department [7].

Research work of students outside the educational process involves participation in the work of subject scientific circles, problem groups, sections, laboratories; participation in the implementation of state budget or self-supporting scientific work; conducting research within the creative cooperation of departments, faculties; work in student information-analytical and culturological centers; lecturing activities; writing articles, abstracts, reports, other publications. This contributes to the formation of a creative attitude to the activity, the development of creative abilities, the development of an installation for multifaceted implementation in the professional sphere by future specialists in road transport.

Implemented in the complex research work of students provides:

- formation of scientific worldview, mastering the methodology and methods of scientific research;

- mastering the specialty and achieving high professionalism;

- development of creative thinking and individual abilities of students in solving practical problems;

- teaching the students the skills of independent research work;

- development of initiative, ability to apply theoretical knowledge in practical work, involvement of capable students in solving scientific problems that are important for theory and practice;

- the need to update and improve their knowledge [7].

The research work of students is a kind of creative activity of students who master the methods of scientific and pedagogical research and skills of their application, knowledge and skills necessary for independent research, develop their creative abilities and personality qualities under the guidance of the teacher [3].

One of the fundamental links in the formation of a specialist that enhances the cognitive and creative activities of students is a scientific-practical conference held in 
extracurricular activities under the supervision of teachers. Scientific-practical conference is a form of involving students in research work, expanding their scientific horizons, acquiring research skills and ensuring high quality professional training. Conferences are held to identify the scientific and creative potential of young people, provide a platform for free exchange of views, stimulate and support the scientific activities of young people, promote their successful career start and professional growth, increase the efficiency of independent work.

The conference helps to solve problems that are of practical importance for the development of science, the real sector of the economy; formation of students' skills of independent work on the study of disciplines that are not included in curricula and programs; improving the quality of training due to a creative approach to the assimilation of additional educational material by students; stimulating young people's interest in current issues; creating conditions for the realization of the innovative potential of youth.

The conference is aimed at supporting and developing scientific activities of students of higher educational institutions, identifying intellectual and creative abilities of students, forming their interest in research, public speaking skills, ability to defend their research and solve practical problems.

Professional training is the main activity of students, thereby determining the performance characteristics of student age. All cognitive processes are professionalized: professional perception and professional observation, professional memory and professional imagination, professional thinking and professional independence. A professional guide to all cognitive processes is formed.

In higher education establishments, education of interest and love for the chosen profession is achieved by developing students' correct ideas about the social significance and content of work in future activities, the patterns of its development: 1) the formation of each student's belief in their professional suitability and a clear understanding of all disciplines, types of training provided by the curriculum of the university; 2) developing a desire to monitor everything progressive in the activities of advanced professionals; 3 ) the ability to direct self-education in favor of work, constantly replenishing their knowledge [2].

Results. In a higher education institution, readiness for a certain type of professional activity is formed, the level of formation of which is determined by the level of formation of competencies and their types. Professional readiness is not only the result but also the goal of professional training, the initial and basic condition for the effective realization of the capabilities of each individual. Readiness, as a complex personal formation, is considered in relation to its two levels. In the first case, readiness is seen as a desire to master a profession, a specialty, in the second as an ability, readiness for professional activity. According to the first level, the component composition is determined as follows:

- motivational: the need for work, interest in the profession, specialties; ideas about social status, prestige of the profession, material interest;

- cognitive: understanding of social significance, the need for the chosen profession, knowledge of ways to achieve the goal; 
- emotional: pride in the profession, aesthetic attitude to professionalism;

- willed: the ability to mobilize their forces, to overcome difficulties in achieving the goal.

At the second level, readiness for professional activity is considered as the formation of the necessary qualities (professional, personal), skills, abilities, and knowledge for its successful implementation [4].

During professional training and professional activity at the university, students develop professional competence - integrated personal quality of a person (his capital), which is formed at the stage of study, is finalized and developed in the process of practical activity. [12].

The final formation and development of professional competence of a specialist occurs only in the process of professional activity.

Conclusions. In the conditions of higher professional education, the acquisition of professional competence by a future specialist deserves special attention. Professional competence is one of the types of key competence and involves the possession of professional activity at a sufficiently high level, the ability of the individual to design their further professional development. Professional competence is the quality of a highly professional worker who is able to realize himself in specific types of work, able to adapt to changing conditions along with the market mechanism that governs professional mobility, professional growth planning and professional self-realization. Our further research will be aimed at creating a model for the formation of professional competence of future motor transport professionals.

\section{References:}

1. Adariukova L.B. (2017) Rozvytok motyvatsiino-tsinnisnoho vidnoshennia studentiv do samoosvitnoi diialnosti yak umova formuvannia samoosvitnoi kompetentnosti [Development of motivational and value attitude of students to selfeducational activity as a condition of formation of self-educational competence] Dukhovnist osobystosti: metodolohiia, teoriia i praktyka. Vyp. 6(81). S. 6-12. [in Ukrainian].

2. Herman Ye.O. (2008) Sotsialno-psykholohichna identychnist suchasnoho studenta [Socio-psychological identity of a modern student]. Visnyk NTUU «KPI». Filosofiia. Pedahohika. Psykholohiia. Vypusk 1(22). S. 30-34. [in Ukrainian].

3. Horkunenko P.I. (2007) Pidhotovka studentiv pedahohichnoho koledzhu do naukovo-doslidnoi roboty [Preparation of students of pedagogical college for research work]: dys. ... kand. Nauk: 13.00.04 Vinnytsia, 265 s. [in Ukrainian].

4. Zeer E., Simanyuk E. (2005) Kompetentnosnyiy podhod k modernizatsii professionalnogo obrazovaniya [Competence-based approach to the modernization of vocational education] Vyisshee obrazovanie v Rossii. №4. S. 23 30. [in Russian].

5. Klovak H.T. (2003) Osnovy pedahohichnykh doslidzhen [Fundamentals of pedagogical research] Navchalnyi posibnyk dlia vyshchykh pedahohichnykh navchalnykh zakladiv. Chernihiv. 260 s. [in Ukrainian].

6. Kompetentnisnyi pidkhid u suchasnii osviti: svitovyi dosvid ta ukrainski perspektyvy. [Competence approach in modern education: world experience and Ukrainian perspectives] Biblioteka z osvitnoi polityky (2004) [pid zah. red. O. V. Ovcharuk] K. 112 s. [in Ukrainian].

7. Krushelnytska O.V. (2006) Metodolohiia ta orhanizatsiia naukovykh doslidzhen. [Methodology and organization of scientific research]. Navchalnyi posibnyk. K.: Kondor. 206 s. [in Ukrainian].

8. Lyubimova G.Yu. (2000) Ot pervokursnika do vyipusknika: problemyi professionalnogo i lichnostnogo samoopredeleniya studentov. [From freshman to graduate: problems of professional and personal self-determination of students] Vestn. Mosk. un-ta. Ser. 14. Psihologiya. № 1. S.34-37. [in Russian].

9. Moroz O.H., Padalka O.S., Yurchenko V.I. (2003) Pedahohika i psykholohiia vyshchoi shkoly [Pedagogy and psychology of high school]. Navchalnyi posibnyk [Za zah. red. O.H. Moroza]. K.: NPU, 267s. [in Ukrainian].

10. Rodyhina I.V. (2008) Kompetentnisno oriientovanyi pidkhid do navchannia [Competence-oriented approach to learning] Seriia «Administratoru shkoly» Kh.: Vyd. hrupa «Osnova», 112 s. [in Ukrainian].

11. Serhiichuk O.M. (2009) Orhanizatsiia pedahohichnoi praktyky u pedahohichnomu universyteti [Organization of pedagogical practice in pedagogical university]: navch.-metod. posibnyk [dlia studentiv, mahistrantiv pedah. un-tiv] Pereiaslav-Khm., 128 s. [in Ukrainian]. 
12. Sysoieva S. (2015) Riznytsia poniat. Chy postrazhdaie zmist zakonu? [The difference of concepts. Will the content of the law be affected?] Osvita: Vseukrainskyi hromadsko-politychnyi tyzhnevyk. № 26-27 (5669-5670). 17-24 chervnia. S. 8. [in Ukrainian].

13. Skakun V.A. (2007) Organizatsiya i metodika professionalnogo obucheniya [Organization and methodology of vocational training]: Uchebnoe posobie. M.: FORUM INFRA. 336s. [in Russian].

Received: April 16, 2021

Approved: May 24, 2021 